FACTA UNIVERSITATIS

Series: Physical Education and Sport, Vol. 16, No 2, 2018, pp. 319 - 327

https://doi.org/10.22190/FUPES181008028D

Research article

\title{
DIFFERENCES BETWEEN LOWER BODY MUSCLE POTENTIAL DURING THE UNLOADED AND LOADED SQUAT JUMP IN ELITE MALE SPRINT SWIMMERS
}

\author{
UDC 796.012:797.21:611.98
}

\section{Marko Đurović, Miloš Nikolić, Miloš Paunović, Dejan Madić, Tomislav Okičić}

Faculty of Sport and Physical Education, University of Niš, Niš, Serbia

\begin{abstract}
The primary purpose was to determine differences between lower body muscle potential during the unloaded and loaded squat jump (SJ) in elite male swimmers. The secondary purpose was to assess the load that would maximize power output in the SJ. Twenty-one elite male trained competitive swimmers, all members of the Central Serbia Swimming Team (Age $=20.7 \pm 3.8$ yrs., Height $=1.84 \pm 0.56 \mathrm{~m}$, Weight $=77.5 \pm 7.3 \mathrm{~kg}$, FINA points 2017 long course $=636 \pm 80)$ performed two trials of the unloaded and loaded SJ (barbell loads equal to 25 and 35\% body weight). Loaded SJ testing with free weights was done using the Smith machine. The Myotest performance measuring system was used to calculate absolute and relative values of average power (Pavg, PavgRel) and maximal power (Pmax, PmaxRel) achieved during the unloaded and loaded SJ. The one-way ANOVA method and POST HOC (Tukey $H S D)$ test were used. The results showed significant interactions between the unloaded and loaded squat jump for relative values of maximal power $(F=12.95, p=0.000)$ and average power $(F=12.20, p=0.000)$ as well as absolute values $(F=7.66, p=0.001$; $F=7.40, p=0.001$ ). The instantaneous power output in the SJ at $0 \%$ additional load (body weight) was significantly greater than that at $25 \%$ and $35 \%$ in the elite male trained competitive swimmers. The practical application of this study suggests that for male sprint swimmers, the load that generates maximal power output in the squat jump is body weight, without any additional load.
\end{abstract}

Key words: maximal power, average power, body weight, swimming

Received October 8, 2018 / Accepted October 11, 2018

Corresponding author: Marko Đurović

University of Niš, Faculty of Sport and Physical Education, Čarnojevića 10a, 18000 Niš, Serbia

Phone: +381 $18510900 •$ E-mail: djura86@yahoo.com 


\section{INTRODUCTION}

A swimming race contains four basic swimming elements - start, turn, swimming distance and finish. The influence of each of these elements is important for the final result, and their individual importance depends on the race distance (Barbosa, Fernandes, Morouco, \& Vilas-Boas, 2008; Cossor \& Mason, 2001; West, Owen, Cunningham, Cook, \& Kilduff, 2011). Some of the previous researches have studied and confirmed a relationship between strength and power characteristics with starting performance (Breed \& Young, 2003; Croin \& Hansen, 2005; Mason, Alcock, \& Fowlie, 2007; Miyashita, Takahashi, Troup, \& Wakayoshi, 1992; West et al., 2011) in elite and sub-elite swimmers. Previous researches (Croin \& Hansen, 2005; Beretić, Đurović, Okičić, \& Dopsaj, 2013) have proved that efficient starting performance depends on lower body strength, so if we want to develop sprinting ability, improvement in lower body strength has to be a priority.

Different kinds of jumps are accepted methods for power testing in swimming (Bishop, Smith, Smith, \& Rigby, 2009; Benjanuvatra, Edmunds, \& Blanksby, 2007; Bishop et al. 2009; Lee, Huang, Wang, \& Lin, 2001; Potdevin, Alberty, Chevutschi, Pelayo, \& Sidney, 2011) as well as other sports (Patterson, Raschner, \& Platzer, 2009; Cormie, Deane, \& McBride, 2007; Bevan et al., 2010). However, optimal load and maximal power output are not well investigated in swimming. Researchers who have dealt with this problem in other sports indicated that in the process of power training the optimal load is that one at which maximum power is achieved (Kaneko, 1983; Kawamori \& Haff, 2004; Moritani, 1987; Moritani, 1993; Wilson et al. 1993; Bevan et al., 2010). In spite of that, some of them have shown that from unloaded jumps to jumps with loads up to $70 \%$ of one repetition maximum (1RM) output of maximum power can occur anywhere (Baker, Nance, \& Moore, 2001; Cormie, McCaulley, Triplett, \& Mcbride, 2007; Cronin \& Hansen, 2005a; Stone et al., 2003) and the results are quite different for male and female athletes. Patterson et al. (2009) investigated optimal load for maximal power output during lower-body resistance exercises in alpine ski teams, and the results have shown that the maximum power was reached at light loads, for males at $25 \%$ body weight $(\mathrm{BW})$ and females at $0 \% \mathrm{BW}$. The biggest part of collecting and reporting power data is the lack of consistency, so it is difficult to compare data from different studies (Cormie et al., 2007b; Cronin \& Sleivert, 2005; Dugan, Doyle, Humphries, Hasson, \& Newton, 2004) and different kinds of sport.

Researchers have confirmed that the most effective training method for power enhancement is work against the body mass (plyometric) or work against external load at various intensity of 1RM (Bevan et al., 2010). However, there is no agreement between researchers in terms of which intensity is the most effective to improve power performance in athletes of the same sport or different sports disciplines. Also, conflict in the literature with regard to optimal load exists for male and female athletes. These numerous disagreements are the consequence of different methodological approaches, used equipment, strength levels of the subjects or sport specific movements (Bevan et al., 2010). Therefore, we have to identify optimal load level for every sport if we would like to reach maximal power output. Further, competitive swimmers have different movement patterns, compared to other sports, and they produce maximal power in the horizontal position where gravity and fluid are also different, so suggested loads for other sports are not appropriate in swimming. According to the authors' knowledge, there are no studies that have investigated the optimum load that enable swimmers to produce maximal power output. 
Therefore, the primary purpose of this study was to the determine differences between lower body muscle potential based on absolute and relative values during different loaded squat jumps (SJ) in elite male swimmers. The secondary purpose was to assess the load that would maximize power output in the SJ. We hypothesized that optimal load for maximal muscle potential in swimmers is different compared to other sports.

\section{METHODS}

\section{The sample of participants}

The overall sample included in this study consisted of 21 male competitive swimmers $($ Age $=20.7 \pm 3.8$ yrs., Height $=1.84 \pm 0.56 \mathrm{~m}$, Body Weight $(\mathrm{BW})=77.5 \pm 7.3 \mathrm{~kg}$, FINA points 2017 - long course $=636 \pm 80$ ), all members of the Central Serbia National Swimming Team. All methods and procedures of this investigation were approved by the ethical committee of the University of Niš, Faculty of Sport and Physical Education, Serbia, and they conformed to the Code of Ethics of the World Health Organization (2001) i.e., Declaration of Helsinki.

\section{Procedures}

Lower body muscle potential was evaluated by applying the Squat Jump test. Myotest performance measuring system was used to evaluate the muscle potential (Myotest SA, Sion, Switzerland) with applied standardized measuring procedures (Izquierdo, Häkkinen, Gonzalez-Badillo, Ibanez, \& Gorostiaga, 2002). The Myotest device is valid for measuring power output $(\mathrm{r}=0.91$; $\mathrm{R} 2=0.82 ; \mathrm{p}<0.05)$ (Bubanj et al., 2011) during the squat jump (Comstock et al., 2011). All tests were performed on the same day at indoor fitness center of the Sports center "Čair" in the city of Nis. All SJ tests for the evaluation of muscle potential characteristics were performed in the afternoon sessions. Before testing, the participants performed a basic warm-up, which contained 5 minutes of cycling and then completed 2 to 3 series of light squats. All of the participants performed two individual tests under each load condition $(0,25$ and $35 \% \mathrm{BW})$, with a 5-minute rest between tests. The jumps was performed from a squat position (the angle of the knees was $\left.90^{\circ}\right)$, for the unloaded $\mathrm{SJ}(0 \%$ BW) the task of the participants was to achieve maximal concentric contraction, without an arm swing, until reaching maximal jump height (Figure 1), legs completely extended (the angle in the knee joint was $180^{\circ}$ ). The tests of the loaded squat jump ( 25 and $35 \% \mathrm{BW}$ ) were done using a Smith machine (Figure 2). Participants were instructed to keep constant downward pressure on the barbell throughout the jump and were encouraged to reach a maximum jump height with every trial in an attempt to maximize power output. The bar was not to leave the shoulders of the participant. If these requirements were not met, the trial was repeated. The data from the more successful attempt were used for analysis (Izquierdo et al., 2002). The participants begin with the unloaded SJ tests, and the loaded SJ tests were performed from lightest to heaviest load.

Swimmers were not involved in strenuous exercises for at least 48 hours before the squat jump test and consumed their normal diet before the testing without any supplement addition. None of the swimmers were injured 6 months before the testing, as well as during the testing process. 


\section{Lower body muscle potential testing}

The evaluation of lower body muscle potential was made by the following procedure for the unloaded and loaded SJ in the Myotest manual. The Myotest instrument was placed on the barbell and set to measure 5 jump attempts. The athlete placed the barbell on his shoulders and stood still. At the long beep, he bent his knees to 90 degrees, stabilized the barbell and stood still. At the short beep, he jumped up as high as possible without any countermovement while firmly keeping the load on his shoulders. The landing was supposed to be as soft and smooth as possible. He returned to the standing position and waited for the next long beep before bending his knees, and for the short beep before jumping. After 5 repetitions, the double beep signaled the end of the test.

The unloaded SJ started in the standing position, hands on hips, facing straight ahead, knees bend to 90 degrees and standing still. At the short beep, the participant jumped as high as possible without any countermovement lunge while keeping his hands on his waist, and the landing was supposed to be as soft and smooth as possible. After the landing, he returned to the previous position with knees bent at 90 degrees and, while standing still, awaited the next beep before repeating the jump. After 5 repetitions, the double beep signaled the end of the test. After the test, the results were automatically displayed on the screen of the Myotest instrument.

The characteristics of lower body muscle potential were represented by: absolute values of average power (Pavg in $\mathrm{W}$ ), relative values of average power (PavgRel in $\mathrm{W} \cdot \mathrm{kg}-1$ ), absolute values of maximal power (Pmax in $\mathrm{W}$ ) and relative values of maximal power (PmaxRel in W·kg-1) achieved during the unloaded and loaded SJ.

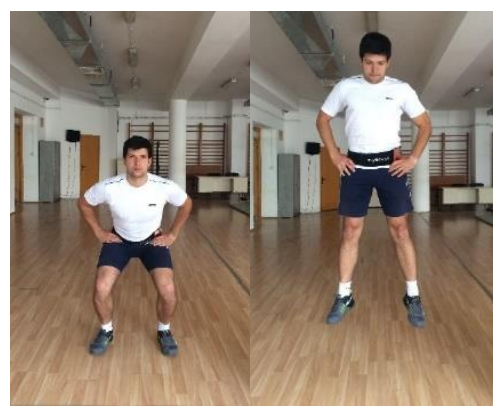

Fig. 1 Unloaded squat jump test

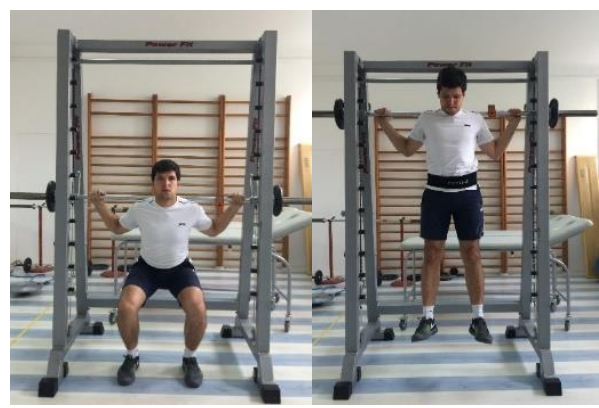

Fig. 2 Loaded squat jump test

\section{Statistical analyses}

For data analysis, the two-way ANOVA design was used to determine differences between lower body muscle potential during different loaded squat jumps. The mean and standard deviation were determined for each variable at each load. All the statistical operations were performed using the software SPSS 19.0. (Chicago, IL, USA), and the level of significance was set at $\mathrm{p} \leq 0.05$. 


\section{RESULTS}

Table 1 shows the results of the descriptive statistics of the applied variables for the evaluation of lower body muscle potential realized in squat jump under different conditions. Based on the results in Table 1, it was determined that the coefficient of variation (CV \%) of the obtained results ranges from 9.8\% (PmaxRel at 0\% BW) up to $16.5 \%$ (Pmax at 35\% BW). The results of the ANOVA indicate that all additional load conditions differ in a statistically significant manner: Pavg $(\mathrm{F}=7.40, \mathrm{p}=0.001), \operatorname{Pmax}(\mathrm{F}=7.66, \mathrm{p}=0.001)$, PavgRel $(\mathrm{F}=12.20$, $\mathrm{p}=0.000)$ and PmaxRel $(\mathrm{F}=12.95, \mathrm{p}=0.000)$. By using the post-hoc test (Tukey HSD), the relative values of maximal power and average power at $0 \%$ were significantly higher than $25 \%$ (PmaxRel, 0 vs. $25 \%=51.34$ vs. $43.58 \mathrm{~W} \cdot \mathrm{kg}-1, \mathrm{p}=0.000$; PavgRel, 0 vs. $25 \%=47.79$ vs. $40.55 \mathrm{~W} \cdot \mathrm{kg}-1, \mathrm{p}=0.000$ ) and $35 \%$ (PmaxRel, 0 vs. $35 \%=51.34$ vs. $44.64 \mathrm{~W} \cdot \mathrm{kg}-1, \mathrm{p}=0.000$; PavgRel, 0 vs. $35 \%=47.79$ vs. $41.89 \mathrm{~W} \cdot \mathrm{kg}-1, \mathrm{p}=0.001)$ as well as absolute values of maximal power and average power at $0 \%$ were significantly higher than $25 \%$ (Pmax, 0 vs. $25 \%=$ 3970.62 vs. $3374.29 \mathrm{~W}, \mathrm{p}=0.002$; Pavg, 0 vs. $25 \%=3696.05$ vs. $3141.43 \mathrm{~W}, \mathrm{p}=0.002$ ) and $35 \%$ (Pmax, 0 vs. $35 \%=3970.62$ vs. $3466.67 \mathrm{~W}, \mathrm{p}=0.009$; Pavg, 0 vs. $35 \%=3696.05$ vs. $3250.95 \mathrm{~W}, \mathrm{p}=0.014)$, respectively. There were no significant differences between 25 and $35 \%$ for all applied variables. Relative values of maximal power and average power output in loaded SJ increased with increasing loading (PmaxRel, $25<35 \%=43.58<44.64 \mathrm{~W} \cdot \mathrm{kg}-1$, p $=0.797$; PavgRel, $25<35 \%=40.55<41.89 \mathrm{~W} \cdot \mathrm{kg}-1, \mathrm{p}=0.668)$, as well as absolute values of maximal power and average power (Pmax, $25<35 \%=3374.29<3466.67 \mathrm{~W}, \mathrm{p}=0.840$; Pavg, $25<$ $35 \%=3141.43<3250.95 \mathrm{~W}, \mathrm{p}=0.754)$.

Table 1 Comparisons of power output in the squat jump for different loading conditions

\begin{tabular}{|c|c|c|c|c|c|c|c|c|c|c|c|c|}
\hline \multirow[t]{2}{*}{ Variables } & \multirow{2}{*}{$\begin{array}{c}\text { Add } \\
\text { Load } \\
(\% \text { BW })\end{array}$} & \multirow[t]{2}{*}{ Mean } & \multirow[t]{2}{*}{ SD } & \multirow[t]{2}{*}{$\mathrm{CV}$} & \multirow[t]{2}{*}{ Min } & \multirow[t]{2}{*}{ Max } & \multicolumn{2}{|c|}{ ANOVA } & \multicolumn{4}{|c|}{ Tukey HSD } \\
\hline & & & & & & & $\mathrm{F}$ & $\mathrm{p}$ & & s. & MD & Sig. \\
\hline \multirow{3}{*}{$\begin{array}{l}\text { Pavg } \\
\text { (W) }\end{array}$} & 0 & 3696.05 & 472.75 & $12.8 \%$ & 3088.00 & 4519.00 & \multirow{3}{*}{\multicolumn{2}{|c|}{$7.40 \mathbf{0 . 0 0 1}$}} & 0 & 25 & 554.62 & 0.002 \\
\hline & 25 & 3141.43 & 488.08 & $15.5 \%$ & 2310.00 & 4250.00 & & & & 35 & 445.10 & 0.014 \\
\hline & 35 & 3250.95 & 522.82 & $16.1 \%$ & 2460.00 & 4350.00 & & & 25 & 35 & -109.52 & 0.754 \\
\hline \multirow{3}{*}{$\begin{array}{l}\text { Pmax } \\
\text { (W) }\end{array}$} & 0 & 3970.62 & 484.05 & $12.2 \%$ & 3209.00 & 5065.00 & \multirow{3}{*}{\multicolumn{2}{|c|}{$7.66 \mathbf{0 . 0 0 1}$}} & 0 & 25 & 596.33 & 0.002 \\
\hline & 25 & 3374.29 & 535.09 & $15.9 \%$ & 2520.00 & 4520.00 & & & & 35 & 503.952 & 0.009 \\
\hline & 35 & 3466.67 & 571.94 & $16.5 \%$ & 2650.00 & 4700.00 & & & 25 & 35 & -92.38 & 0.840 \\
\hline \multirow{3}{*}{$\begin{array}{l}\text { PavgRel } \\
\left(\mathrm{W} \cdot \mathrm{kg}^{-1}\right)\end{array}$} & 0 & 47.79 & 5.09 & $10.6 \%$ & 37.00 & 55.70 & \multirow{3}{*}{\multicolumn{2}{|c|}{$12.20 \mathbf{0 . 0 0 0}$}} & 0 & 25 & 7.24 & 0.000 \\
\hline & 25 & 40.55 & 5.12 & $12.6 \%$ & 31.94 & 50.60 & & & & 35 & 5.90 & 0.001 \\
\hline & 35 & 41.89 & 4.94 & $11.8 \%$ & 34.46 & 51.31 & & & 25 & 35 & -1.34 & 0.668 \\
\hline \multirow{3}{*}{$\begin{array}{l}\text { PmaxRel } \\
\left(\mathrm{W} \cdot \mathrm{kg}^{-1}\right)\end{array}$} & 0 & 51.34 & 5.04 & $9.8 \%$ & 39.10 & 60.30 & \multirow{3}{*}{12.95} & \multirow{3}{*}{0.000} & 0 & 25 & 7.76 & 0.000 \\
\hline & 25 & 43.58 & 5.80 & $13.3 \%$ & 33.77 & 53.81 & & & & 35 & 6.70 & 0.000 \\
\hline & 35 & 44.64 & 5.20 & $11.7 \%$ & 36.26 & 55.83 & & & 25 & 35 & -1.06 & 0.797 \\
\hline
\end{tabular}

Abbreviations: Add Load (kg) = Body weight + additional load, Mean = Arithmetic mean,

$\mathrm{SD}=$ Standard Deviation, $\mathrm{CV}=$ coefficient of variation, $\mathrm{Min}=$ Minimum value, Max $=$ Maximum value, ANOVA = Analysis of variance, Tukey HSD = Tukey's Honest Significant Difference test, $\mathrm{MD}=$ Mean Difference, Sig. = level of significance. 


\section{DISCUSSION}

This study included 21 male competitive sprint swimmers. The aim of this study was to determine differences between lower body muscle potential during different loaded squat jumps in elite male swimmers and assess the load that would maximize power output in the SJ.

The results of this research indicate there is a statistically significant difference between the unloaded $(0 \% \mathrm{BW})$ and loaded SJ (25 and 35\% BW), also the unloaded SJ could correspond to a resistance high enough for the production of maximal power output in elite male swimmers, i.e. power output was maximized at a relative intensity of $0 \%$ of additional load (body weight alone) during the SJ. Their relative values of maximal power were similar to those of elite water polo goal keepers (swimmers vs. water polo goal keepers $=51.34 \mathrm{vs}$. $52.02 \mathrm{~W} \cdot \mathrm{kg}-1$ ) assessed by Corrêa, Bertuzzi, Romano, Alves, \& Guimarães (2007), who were presented with a similar SJ test protocol. In addition, Corrêa et al. (2007) carried out a study which included a sample of three elite water polo goal keepers ( 1 female and 2 male) with the aim of describing the preliminary results of the effects of additional loading on relative values of maximal power output during the SJ, and concluded that the maximum was reached at $0 \%$ additional load by two of the athletes, and for the third, the maximal power output was reached at $5 \%$ of additional load of BW. In a study which included 47 professional male rugby players, Bevan et al. (2010) also concluded that the maximal power output was produced when the athletes worked against an additional load equal to $0 \%$ of 1RM for the lower body (Effect Size $\eta 2: 0.709, \mathrm{p}<0.001$ ) and 30\% of 1RM for the upper body (effect size $\eta 2: 0.297, \mathrm{p}<0.001$ ). The squat jump test results from this study are in line with those reported for professional rugby players and it can be noticed that they have achieved higher absolute values of power output (swimmers vs. rugby players $=3970.62 \pm$ 484.05 vs. $4750.9 \pm 529.4 \mathrm{~W}$ ); also their body mass is different (swimmers vs. rugby players $=77.5 \pm 7.3 \mathrm{~kg}$ vs. $101.3 \pm 12.8 \mathrm{~kg}$ ) which indicates that elite swimmers have higher relative values of power output (swimmers vs. rugby players $=51.34 \mathrm{vs} .46 .90 \mathrm{~W} \cdot \mathrm{kg}-1$ ). Cormie et al. (2007a) also suggest that the optimal load to achieve maximal power output in the SJ for male athletes (football players, sprinters, long jumpers) is $0 \%$ of $1 \mathrm{RM}$. When it comes to sedentary individuals (Driss et al., 2001), the maximal power output in the SJ at $0 \mathrm{~kg}$ (Pmax $=43.2 \pm 6.0 \mathrm{~W} \cdot \mathrm{kg}-1)$ was greater than that at $5(\mathrm{Pmax}=41.9 \pm 5.2 \mathrm{~W} \cdot \mathrm{kg}-1)$ and $10 \mathrm{~kg}$ $($ Pmax $=41.2 \pm 5.6 \mathrm{~W} \cdot \mathrm{kg}-1)$. On the other hand, Patterson et al. (2009) in a study which included a sample of 37 (20 male and 17 female) Austrian alpine skiers found that optimal additional loading for maximal power output during the unloaded and loaded squat jump is light loads (for males at $25 \% \mathrm{BW}$ and females at $0 \% \mathrm{BW}$ ), which was not the case in our study. For example, in the study carried out by Izquierdo et al. (2002) which included a sample of 70 male athletes from different sports (weightlifting, handball, road cycling, middle-distance running and control group), with the aim of determining the optimal load for maximal power output, they concluded that maximal power output was produced at higher loads (45-60\% of 1RM) in the SJ. Maximal power output was produced at a load of $60 \%$ for handball, middle-distance running and the control group, and at a load of $45 \%$ for weightlifting and road cycling. Such differences can be explained by differences in muscle characteristics and by different training backgrounds.

In the current study, the maximal power values were $17 \%$ higher at a load of $0 \% \mathrm{BW}$ than in $25 \% \mathrm{BW}$, as well as $14 \%$ higher than the load of $35 \% \mathrm{BW}$. This suggests that the 
maximal power output for the SJ was higher in the $0 \%$ than in the $25 \%$ and $35 \% \mathrm{BW}$ in elite male swimmers. Therefore, body weight alone could be an optimal load enough for the production of maximal power in some sports events (Corrêa et al., 2007a; Bevan et al., 2010; Cormie et al., 2007; Driss et al., 2001). On the other hand, body weight could be lower than the optimal load for maximal power in athletes (Patterson et al., 2009; Izquierdo et al., 2002). The obtained results confirm our assumption that the optimal load for maximal muscle potential in swimmers is different compared to other sports.

\section{CONCLUSION}

The practical applications of this study are reflected in the fact that athletes and coaches are aware of the additional load for maximal power production, as well as that athletes should train using the load at which muscle power output is maximized. This study highlights that body weight alone could be an optimal additional load enough for the production of maximal power output in elite male swimmers. The results of this study may also be useful for creating optimal dry land power training for swimmers. For future studies, we intend to investigate the repetitions, sets and recovery interval combinations for training to improve maximal power production.

\section{REFERENCES}

Baker, D., Nance, S., \& Moore, M. (2001). The load that maximizes the average mechanical power output during jump squats in power-trained athletes. Journal of Strength and Conditioning Research, 15(1), 92-97.

Barbosa, T. M., Fernandes, R. J., Morouco, P., \& Vilas-Boas, J. P. (2008). Predicting the intra-cyclic variation of the velocity of the center of mass from segmental velocities in butterfly stroke: A pilot study. Journal of Sports Science \& Medicine, 7(2), 201-209.

Benjanuvatra, N., Edmunds, K., \& Blanksby, B. (2007). Jumping abilities and swimming grab-start performances in elite and recreational swimmers. International Journal of Aquatic Research and Education, 1(3), 231-241.

Beretić, I., Đurović, M., Okičić, T., \& Dopsaj, M. (2013). Relations between lower body isometric muscle force characteristics and start performance in elite male sprint swimmers. Journal of Sports Science \& Medicine, 12(4), 639-645.

Bevan, H.R., Bunce, P.J., Owen, N.J., Bennett, M.A., Cook, C.J., Cunningham, D.J., et al. (2010). Optimal loading for the development of peak power output in professional rugby players. Journal of Strength \& Conditioning Research, 24(1), 43-47.

Bishop, D.C., Smith, R.J., Smith, M.F., \& Rigby, H.E. (2009). Effect of plyometric training on swimming block start performance in adolescents. The Journal of Strength \& Conditioning Research, 23(7), 2137-2143.

Breed, R.V., \& Young, W.B. (2003). The effect of a resistance training programme on the grab, track and swing starts in swimming. Journal of Sports Sciences, 21(3), 213-220.

Bubanj, S., Okičić, T., Živković, M., Stanković, R., Bojić, I., \& Bubanj, R. (2011). Differences in manifested explosive strength tested by means of the vertical jump with and without previous static stretching. Facta Universitatis Series Physical Education and Sport, 9(2), 151-159.

Comstock, B.A., Solomon-Hill, G., Flanagan, S.D., Earp, J.E., Luk, H.Y., Dobbins, K. A., et al. (2011). Validity of the Myotest ${ }^{\circledR}$ in measuring force and power production in the squat and bench press. The Journal of Strength \& Conditioning Research, 25(8), 2293-2297.

Cormie, P., Deane, R., \& McBride, J.M. (2007a). Methodological concerns for determining power output in the jump squat. Journal of Strength and Conditioning Research, 21(2), 424-430.

Cormie, P., McCaulley, G.O., Triplett, N.T., \& Mcbride, J.M. (2007b). Optimal loading for maximal power output during lower-body resistance exercises. Medicine and Science in Sports and Exercise, 39(2), 340-349. 
Corrêa, S.C., Bertuzzi, R.C.D.M., Romano, R.G., Alves, F., \& Guimarães, G. (2007). Effects of external loading on power output during vertical jump: a pilot study with water polo goal keepers. 25 International Symposium on Biomechanics in Sports. In: H.J. Menzel, \& M.H. Chagas (Eds.), Book of Proceedings (pp. 220-223), Ouro Preto - Brazil.

Cossor, J., \& Mason, B. (2001). Swim start performance at the Sydney 2000 Olympics. In Blackwell, J.R., \& Sanders, R.H. (Eds). 19 International Symposium on Biomechanics in Sports. Book of Proceedings (pp. 70-74), San Francisco: University of California at San Francisco.

Cronin, J.B., \& Hansen, K.T. (2005). Strength and power predictors of sports speed. Journal of Strength and Conditioning Research, 19(2), 349-357.

Cronin, J., \& Sleivert, G. (2005). Challenges in understanding the influence of maximal power training on improving athletic performance. Sports Medicine, 35(3), 213-234.

Driss, T., Driss, T., Vandewalle, H., Quièvre, J., Miller, C., \& Monod, H. (2001). Effects of external loading on power output in a squat jump on a force platform: a comparison between strength and power athletes and sedentary individuals. Journal of Sports Sciences, 19(2), 99-105.

Dugan, E.L., Doyle, T.L., Humphries, B., Hasson, C.J., \& Newton, R.U. (2004). Determining the optimal load for jump squats: A review of methods and calculations. Journal of Strength \& Conditioning Research, 18(3), 668-674.

Izquierdo, M., Häkkinen, K., Gonzalez-Badillo, J.J., Ibanez, J., \& Gorostiaga, E.M. (2002). Effects of longterm training specificity on maximal strength and power of the upper and lower extremities in athletes from different sports. European Journal of Applied Physiology, 87(3), 264-271.

Kaneko, M. (1983). Training effect of different loads on the force-velocity relationship and mechanical power output in human muscle. Scandinavian Journal of Medicine and Science in Sports, 5, 50-55.

Kawamori, N., \& Haff, G.G. (2004). The optimal training load for the development of muscular power. Journal of Strength and Conditioning research, 18(3), 675-684.

Lee, C., Huang, C., Wang, L., \& Lin, D. C. (2001). Comparison of the dynamics of the swimming grab start, squat jump, and countermovement jump of the lower extremity. International Symposium on Biomechanics in Sports. Book of Proceedings (pp. 143-146).

Mason, B., Alcock, A., \& Fowlie, J. (2007). A kinetic analysis and recommendations for elite swimmers performing the sprint start. 25 International Symposium on Biomechanics and Sport. In Menzel, H. J, \& Chagas (Eds.), Book of Proceedings (pp. 192-195), Ouro Preto: Brazil

Miyashita, M., Takahashi, S., Troup, J. P., \& Wakayoshi, K. (1992). Leg extension power of elite swimmers. In: Biomechanics and medicine in swimming, $6^{\text {th }}$ Edition. In D. MacLaren, T. Reily, \& A. Less. (pp. 295301), London: E \& FN Spon.

Moritani, T. (1987). Electrophysiological analyses of the effects of muscle power training. Research Journal of Physical Education in Japan, 1, 23-32.

Moritani, T. (1993). Neuromuscular adaptations during the acquisition of muscle strength, power and motor tasks. Journal of Biomechanics, 26, 95-107.

Patterson, C., Raschner, C., \& Platzer, H.P. (2009). Power variables and bilateral force differences during unloaded and loaded squat jumps in high performance alpine ski racers. Journal of Strength \& Conditioning Research, 23(3), 779-787.

Potdevin, F.J., Alberty, M.E., Chevutschi, A., Pelayo, P., \& Sidney, M.C. (2011). Effects of a 6-week plyometric training program on performances in pubescent swimmers. Journal of Strength and Conditioning Research, 25(1), 80-86.

Stone, M.H., O'bryant, H.S., Mccoy, L., Coglianese, R., Lehmkuhl, M., \& Schilling, B. (2003). Power and maximum strength relationships during performance of dynamic and static weighted jumps. Journal of Strength and Conditioning Research, 17(1), 140-147.

West, D.J., Owen, N.J., Cunningham, D. J., Cook, C.J., \& Kilduff, L.P. (2011). Strength and power predictors of swimming starts in international sprint swimmers. The Journal of Strength \& Conditioning Research, 25(4), 950-955.

Wilson, G.J., Newton, R.U., Murphy, A.J., \& Humphries, B.J. (1993). The optimal training load for the development of dynamic athletic performance. Medicine and Science in Sports and Exercise, 25(11), 1279-1286.

World Health Organization (2001). World Medical Association-Declaration of Helsinki. Bulletin of the World Health Organization, 79, 373-374. 


\section{RAZLIKA IZMEĐU MIŠIĆNOG POTENCIJALA DONJIH EKSTREMITETA OSTVARENOG KROZ VERTIKALNI SKOK SA I BEZ OPTEREĆENJA KOD ELITNIH PLIVAČA}

Primarni cilj je bio utvrditi razliku između mišićnog potencijala donjih ekstremiteta tokom vertikalnog skoka (SJ) sa i bez opterećenja kod elitnih plivača. Sekundarni cilj je bio da se proceni optimalno opterećenje pri kome se ispoljava najveća mišićna snaga donjih ekstremiteta prilikom SJ. Uzorak ispitanika je činio 21 plivač, svi plivači su članovi Nacionalnog tima Plivačkog saveza centralne Srbije (Uzrast $=20.7 \pm 3.8$ god., Telesna visina $=1.84 \pm 0.56 \mathrm{~m}$, Telesna masa $=77.5 \pm 7.3 \mathrm{~kg}$, FINA bodovi 2017 veliki bazen $=636 \pm 80$ ). Ispitanici su izvršili po dva testovna pokušaja za svaki skok (bez opterećenja, sa dodatnim opterećenjem od 25\% telesne mase $i$ sa dodatnim opterećenjem od $35 \%$ telesne mase). Vertikalni skok sa opterećenjem je izvođen pomoću Smit mašine iz pozicije polučučnja (ugao u zglobu kolena $\left.90^{\circ}\right)$. Vertikalni skok bez opterećenja je izvođen, takođe iz polučučnja bez zamaha rukama. Myotest uređaj je korišćen u proceni apsolutnih i relativnih vrednosti prosečne mišićne snage donjih ekstremiteta (Pavg, PavgRe) i maksimalne mišićne snage donjih ekstremiteta (Pmax, PmaxRel) ostvarenih kroz SJ sa i bez opterećenja. Da bi se utvrdila statistički značajna razlika između između mišićnog potencijala donjih ekstremiteta tokom SJ sa i bez opterećenja koristila se ANOVA i post hok test (Tukey HSD). Dobijeni rezultati ukazuju da postoji statistički značajna razlika između mišićnog potencijala donjih ekstremiteta tokom $S J$ sa i bez opterećenja u svim primenjenim varijablama: PavgRel $(F=12.95$, $p=0.000)$, PmaxRel (F=12.20, $p=0.000), \operatorname{Pavg}(F=7.66, p=0.001) i \operatorname{Pmax}(F=7.40, p=0.001)$. Ostvareni mišićni potencijal donjih ekstremiteta kroz SJ bez opterećenja ( $0 \%$ dodatnog opterećenja) je statistički značajno veći nego kroz SJ sa opterećenjem od $25 \%$ telesne mase (BW) kao i sa opterećenjem od 35\% BW kod ispitivanih plivača. Praktična primenljivost sprovedenog istraživanja se ogleda u tome da je utvrđeno da plivači proizvode maksimalnu snagu kroz SJ bez dodatnog opterećenja, odnosno samo sa sopstvenom telesnom masom.

Ključne reči: maksimalna snaga, prosečna snaga, telesna masa, plivanje 